\title{
PENGEMBANGAN MODUL PEMBELAJARAN MATA KULIAH TEKNOLOGI PANGAN (TP)
}

\author{
Yensasnidar $^{1}$, Yuliana $^{2}$, Anni Faridah ${ }^{2}$ \\ ${ }^{1}$ Alumni Program Magister Pendidikan Teknologi FakultasTeknik \\ ${ }^{2}$ Dosen Fakultas Pariwisata dan Perhotelan Universitas Negeri Padang \\ e-mail: yensasnidar@gmail.com
}

\begin{abstract}
This research is motivated by several problems which are identified in the subject of Food Technology, namely the existing module has not facilitated the students to study individully, it has not been suitable to the theories of module development, the students are not independent and active in learning process, it is necessary to develop the learning module of Food Technology which is suitable to the standard of competency. The purpose of this research is to produce the valid, practical and effective learning module in order to be used in learning process.This reaserch was carried out by using research method and development of Research and Development $(R \& D)$ with four-D development model (4D). the steps of $4 D$ development are Define (definition), Design (design), Develop (development) and Disseminate (Dissemination). The results of this development research are as follows; (1) learning module of food technology subject; and the aspect of module format which is stated as valid with value total 0,83\%; (2) the validity of learning module in material aspectof module (valid) is 0,85\%; (3) practicality of learning module that is based on lecturer's response is stated as very practical with value total $96,9 \%$ and based on student's respons is stated very practical with value total 84,27\%; (4) the effectiveness of learning module is stated as effective in improving student learning result. Based on the findings of this study were concluded that this learning module is valid, very practical, and effective to be used as teaching material of food technology subject.
\end{abstract}

Keywords: Validity, Practicality, Effectiveness

\section{Pendahuluan}

Pendidikan merupakan sebuah proses, baik formal maupun informal dimana adanya upaya suatu bangsa dalam memelihara dan mengembangkan nilai-nilai diberbagai bidang kehidupan. Berbagai usaha telah dilakukan pemerintah melalui dunia pendidikan, bahwa berhasil tidaknya pencapaian tujuan pendidikan bergantung kepada bagaimana proses pembelajaran itu dilaksanakan. Adapun salah satu tingkat keberhasilan proses belajar mengajar adalah ditujukan dengan tercapainya standar prestasi belajar mahasiswa yang diharapkan, karena merupakan sarana untuk membentuk sumber daya manusia yang berkualitas, baik dari segi fisik, mental maupun operasional.

Pendidikan kejuruan tidak hanya menciptakan mahasiswa yang dapat bekerja setelah tamat, namun pendidikan kejuruan juga menciptakan mahasiswa yang dapat membuka lapangan kerja sendiri salah satunya dalam berwirausaha (Ganefri, 2013:8). Sehubungan dengan peningkatan 
kualitas pendidikan, peran pendidik sangat menentukan dalam menyelenggarakan proses pembelajaran yang berkualitas. Proses pembelajaran dikatakan bermutu bila dalam proses pembelajaran tersebut mahasiswa dapat mencapai tujuan pembelajaran yang diharapkan, adalah modul pembelajaran.

Modul pembelajaran merupakan satuan program belajar mengajar yang terkecil, yang dipelajari oleh mahasiswa sendiri secara perseorangan atau diajarkan oleh mahasiswa kepada dirinya sendiri (self instructional) (Winkel, 2009:472). Menurut Direktur Jendral Penjaminan Mutu Pendidikan dan tenaga kependidikan (2008:3). Modul merupakan bahan ajar cetak yang dirancang untuk dapat dipelajari secara mandiri oleh peserta didik, karena modul yang baik harus disusun secara sistematis, menarik, dan jelas.

Pemilihan modul ini disesuaikan dengan memperhatikan karakteristik dan kemampuan serta kondisi kelas. Modul merupakan bahan ajar yang terdiri dari materi, metode, batasan-batasan dan evaluasi yang disusun secara sistematis dan menarik. Modul mampu digunakan secara mandiri karena di dalam modul terdapat contoh yang mendukung kejelasan materi, terdapat soal latihan dan tugas, terdapat rangkuman dan evaluasi (self instructional).

Materi pembelajaran yang terdapat dalam modul dikemas dalam unit kegiatan yang utuh, sehingga memudahkan dipelajari secara tuntas (self contained), modul memiliki karakteristik stand alone yaitu modul tidak tergantung pada media lain, sesuai dengan perkembangan ilmu pengetahuan dan teknologi serta fleksible (adaptif) dan bersahabat dengan penggunanya (user friendly),

Modul banyak diterapkan dalam pembelajaran, baik di SMK maupun di sekolah tinggi ilmu kesehatan dan di universitas. Pelaksanaan kegiatan pembelajaran materi mata kuliah Teknologi Pangan selama ini, masih kurang maksimal dan kurang efektif, hal ini terlihat dari kurangnya panduan belajar mahasiswa, seperti modul atau perangkat pembelajaran. Materi yang diberikan masih terfokus kepada dosen. Mata kuliah Teknologi Pangan merupakan salah satu mata kuliah yang menuntut mahasiswanya untuk aktif dan kreatif dalam proses pembelajaran. Namun, kegiatan pembelajaran mahasiswa pada mata kuliah Teknologi Pangan sering kali kurang memadai dalam pencapaian keberhasilan akademik.

Hal ini dapat dilihat observasi awal yang penulis lakukan, wawancara dengan dosen pengampu yang terkait pada mata kuliah Teknologi Pangan. Salah satu masalah yang ditemukan adalah modul yang idealnya adalah modul yang disusun secara sistematis yang mencakup isi materi, metode dan 
evaluasi dan dapat belajar mandiri dan mencakup kompetensi yang diharapkan, namun kenyataanya modul yang ada belum mempasilitasi mahasiswa belajar secara mandiri. Adanya modul yang tak digunakan saat proses pembelajaran dikarenakan modul yang ada belum sesuai dengan harapan dari segi susunan yang diinginkan. Struktur modul yang ada belum cocok dengan teori- teori pengembangan modul. Mahasiswa kurang mandiri dan tidak aktif dalam proses pembelajaran karena penyampaian materi dilakukan dengan metode ceramah sehingga mahasiswa hanya mengandalkan pembelajaran dikelas.

Modul pembelajaran yang dikembangkan dengan memodifikasi modul pembelajaran yang ada agar dapat meningkatkan kualitas proses belajar mahasiswa. Dengan adanya pengembangan modul pembelajaran, bahan ajar juga dapat menarik perhatian mahasiswa sehingga dapat menumbuhkan motivasi belajar mahasiswa dan mahasiswa dapat belajar mandiri. Modul Teknologi Pangan dapat dijadikan bahan ajar oleh dosen dan mahasiswa. Berdasarkan permasalahan yang ada, penulis ingin mengangkat penelitian dengan judul Pengembangan Modul Pembelajaran Mata Kuliah Teknologi Pangan (TP). Tujuan dari penelitian ini mengembangkan modul pembelajaran mata kuliah Teknologi Pangan yang valid, praktis, dan efektif .

\section{Studi Pustaka}

\section{Modul}

Modul merupakan bahan ajar yang dibuat oleh dosen yang disusun secara sistematis untuk digunakan mahasiswa dalam proses pembelajaran. Modul merupakan suatu unit program pengajaran yang disusun dalam bentuk tertentu untuk keperluan belajar, Modul merupakan bahan ajar cetak yang dirancang untuk dapat dipelajari secara mandiri (Ditjen PMPTK, 2008). Anwar (2010) menyatakan bahwa modul pembelajaran adalah bahan ajar yang disusun secara sistimatis dan menarik yang mencakup isi materi, metode dan evaluasi yang dapat digunakan secara mandiri untuk mencapai kompetensi yang diharapkan. Modul pembelajaran merupakan salah satu bahan ajar yang dapat dimanfaatkan oleh mahasiswa secara mandiri karena modul yang baik harus disusun secara sistematis, menarik, dan jelas.

\section{Model Pengembangan four- $D$}

Model pengembangan yang digunakan yaitu four-D, model pengembangan 4-D ini telah divalidasi oleh konsorium empat perguruan tinggi: Michigan State University, Syracuse Uversity, The United States International University, dan The University of Southern California. Pengembangan model four D menerapkan 
prinsip-prinsip pendekatan sistem, yaitu pengembangan (develop). Tahapan ini dihubungkan dengan umpan balik (feedback) untuk mengadakan revisi.Pada tahap pengembangan (Develop) terdapat tahapan yang dilakukan, yaitu rancangan awal (prototype), tahapan validitas dan tahapan uji praktikalitas.

\section{Teknologi Pangan}

a) Deskripsi Mata Kuliah Teknologi Pangan adalah mata kuliah Teknologi Pangan adalah Mata kuliah ini membahas berbagai teknik/metode pengolahan dan pengawetan pangan sesuai dengan sifat pangan dengan mempertahankan dan meningkatkan mutu, kadar dan nilai gizi pangan.

b) Tujuan mata kuliah Teknologi Pangan adalah pada akhir pendidikan mata kuliah ini, peserta didik diharapkan mampu memahami berbagai teknik/metode pengolahan dan pengawetan pangan sesuai dengan sifat pangan dengan mempertahankan dan meningkatkan mutu, kadar dan nilai gizi pangan.

\section{Metode}

Jenis Penelitian yang di gunakan adalah penelitian dan pengembangan (Research and Development/ R\&D). Model yang digunakan dalam penelitian ini adalah model pengembangan 4-D (Define, Design, Develop dan Disseminate). Tahap Penyebaran (Dessiminate) pada penelitian ini tidak dilakukan karena mengingat keterbatasan waktu dan biaya peneliti.

Bagian yang dilakukan dalam tulisan ini yaitu develop, dengan tahapan 1) Rancangan Awal, 2) tahapan validitas, 3) tahapan uji praktikalitas 4) tahap efektivitas. Tujuan peneliti memilih bagian develop ini, karena peneliti hanya mengembangkan modul pembelajaran teori mata kuliah Teknologi Pangan yang valid, praktis dan efektif, agar modul ini dapat digunakan oleh mahasiswa dan dosen.

Pada tahap validasi terdapat 8 validator, yaitu 3 validator format modul, 5 validator materi. Subjek dari penelitian ini yaitu dosen mata kuliah Teknologi Pangan dan mahasiswa Gizi STIKes Perintis Padang yang mengambil mata kuliah Teknologi Pangan.Uji coba yang dilakukan adalah 1) uji validitas, 2) uji praktikalitas, 3) uji efektifitas. Pada uji validitas yang dilakukan yaitu untuk mencari ke validan modul tersebut dengan menggunakan rumus aiken's v. Uji praktikalitas yang dinilai kepraktisannya oleh dosen dan mahasiswa.

\section{Uji Validitas}

Indikator validitas berdasarkan lembar validasi, dengan langkahlangkah: 
a) Melakukan penskoran masing-masing item yang divalidasi skala 1-4 dengan ketentuan:

Nilai 4 = Sangat Setuju

Nilai $3=$ Setuju

Nilai 2 = Kurang Setuju

Nilai $1=$ Tidak Setuju

b) Menjumlahkan skor dari tiap validator untuk seluruh indikator menggunakan koefisien Aiken V, penilaian dilakukan dengan cara memberikan angka antara 1 sampai dengan 4.

c) Untuk menentukan kevalidan modul pembelajaran berbasis mata kuliah Teknologi Pangan yang dikembangkan, menggunakan rumus Aiken V

$\mathrm{V}=\sum \mathrm{s} /[\mathrm{n}(\mathrm{c}-1)]$

\section{Keterangan:}

$\mathrm{s} \quad=\mathrm{r}-1 \mathrm{o}$

lo = Angka penilaian validitas yang rendah (dalam hal ini $=1)$

$\mathrm{c}=$ Angka penilaian validitas yang tertinggi (dalam hal ini $=4)$

$\mathrm{r}=$ Angka yang diberikan oleh seorang penilai

d) Hasil dari perhitungan Aiken berkisar antara 0 sampai 1 dan angka 0,67 dapat diinterpretasikan memiliki koefisien cukup tinggi. Nilai V 0,67 dan di atasnya dinyatakan dalam kategori Valid.
2 Uji Praktikalitas Modul

Uji praktikalitas yang dinilai kepraktisannya oleh dosen dan mahasiswa adalah dianalisis dengan menggunakan statistik deskriptif dan dilakukan dengan mengikuti beberapa langkah-langkah dalam Riduwan (2010:89) sebagai berikut:

a. Skor Jawaban dengan kriteria sebagai berikut:

$$
\begin{aligned}
& 1 \text { = Tidak Setuju } \\
& 2=\text { Kurang Setuju } \\
& 3=\text { Setuju } \\
& 4=\text { Sangat Setuju }
\end{aligned}
$$

b. Menentukan skor rata-rata yang didapat dengan cara menjumlahkan nilai yang didapat dari banyak indicator.

c. Setelah seluruh skor item diperoleh, kemudian ditabulasikan berdasarkan setiap aspek kepraktisan dan dicari persentasenya dengan rumus:

Nilai praktikalitas dengan rumus:

$$
\mathrm{NA}=\frac{s}{M} x 100 \%
$$

Keterangan:

$$
\begin{array}{ll}
\mathrm{NA} & =\text { Nilai akhir } \\
\mathrm{S} & =\text { Skor yang didapat } \\
\mathrm{SM} & =\text { Skor maksimum }
\end{array}
$$

d. Menentukan tingkat kepraktisan modul pembelajaran dengan kriteria pada tabel 1 .

\section{Uji Efektivitas Modul}




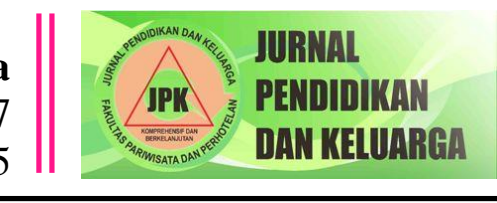

Uji analisis efektifitas modul yang dilihat dari hasil belajar mahasiswa yaitu dengan membandingkan hasil belajar mahasiswa kelas eksperimen dengan kelas kontrol. Uji efektivitas dilakukan dengan posttest One-Group Pretest Posttest Design yaitu dengan pengujian 2 kelas berbeda, dengan membandingkan $80 \%$ hasil belajar mahasiswa dikatakan efektif.

Tabel 1.Kategori Praktikalitas Modul

\begin{tabular}{|c|c|c|}
\hline No & $\begin{array}{c}\text { Tingkat Pencapaian } \\
(\%)\end{array}$ & Kategori \\
\hline 1 & $81-100$ & Sangat Praktis \\
\hline 2 & $61-80$ & Praktis \\
\hline 3 & $41-60$ & Cukup Praktis \\
\hline 4 & $21-40$ & Kurang Praktis \\
\hline 5 & $0-21$ & Tidak Praktis \\
\hline
\end{tabular}

Sumber: Riduwan (2010:89)

Pengujian signifikansi dapat dilakukan dengan melakukan uji t ( $t$-test). pada hasil tes dengan melihat hasil uji $t$, apabila hasil analisis didapati nilai $\mathrm{t}$ hitung $>\mathrm{t}$ tabel maka dapat diarti kan terdapat perbedaan yang signifikan antara hasil tes mahasiswa kelas eksperimen dengan kelas kontrol.

Tabel 2 Kriteria taraf keberhasilan belajar

\begin{tabular}{|c|c|l|}
\hline No. & $\begin{array}{c}\text { Tingkat } \\
\text { Pencapaian } \\
(\boldsymbol{\%})\end{array}$ & Kategori \\
\hline 1 & $81 \%-100 \%$ & Sangat efektif \\
\hline 2 & $61 \%-80 \%$ & Efektif \\
\hline 3 & $41 \%-60 \%$ & Cukup efektif \\
\hline
\end{tabular}

\begin{tabular}{|l|l|l|}
\hline 4 & $20 \%-40 \%$ & Kurangefektif \\
\hline 5 & $<20 \%$ & Tidak efektif \\
\hline
\end{tabular}

Sumber: Anas (2009)

\section{Hasil dan Pembahasan}

\section{Hasil}

Hasil penelitian ini adalah mengetahui validitas, praktikalitas dan efektivitas modul pembelajaran Teknologi Pangan. Penelitian ini melakukan beberapa tahapan, yaitu:

a. Tahap Perancangan

Pada tahap perancangan modul pembelajaran mata kuliah Teknologi Pangan, peneliti melakukan beberapa tahap yaitu 1) Penentuan sistematika penyajian materi yang disesuaikan dengan silabus, yaitu: (a) pengantar teknologi pangan (b) teknologi kerusakan pangan (c) teknologi bahan tambahan pangan (BTP) teknologi pengawetan garam, asam, gula (e) teknologi pengawetan fermentasi (f) teknolog pengawetan suhu tinggi (g) teknologi pengawetan suhu rendah (h) peningkatan mutu gizi pangan, (i) teknologi pengeringan pangan, (j) teknologi pengemas pangan, $(\mathrm{k})$ teknologi penyimpanan pangan.

2) Penyususanan kerangka dalam modul pembelajaran yaitu desain tampilan modul pembelajaran Teknologi Pangan

b. Tahapan Validitas

Tahapan validasi ini, peneliti memberikan angket kepada 8 orang validator yang memvalidasi pengembangan 
modul pembelajaran mata kuliah Teknologi Pangan .3 validator format modul dan 5 validator materi. Hasil penilaian dari masing-masing aspek yang diberikan validator dianalisis menggunakan rumus statistik Aiken's V. Hasil validasi yang dirangkum berdasarkan aspek yang dinilai sebagaimana terlihat pada Tabel 2 dan 3.

Tabel 2. Hasil Validasi Format Modul

\begin{tabular}{|c|l|c|c|}
\hline No & \multicolumn{1}{|c|}{ Aspek } & $\begin{array}{c}\text { Rata- } \\
\text { rata }\end{array}$ & Kategori \\
\hline 1 & $\begin{array}{l}\text { Aspek } \\
\text { kelayakan } \\
\text { penyajian }\end{array}$ & 0,82 & Valid \\
\hline 2 & $\begin{array}{l}\text { Aspek } \\
\text { kualitas } \\
\text { pembelajaran }\end{array}$ & 0,83 & Valid \\
\hline 3 & $\begin{array}{l}\text { Aspek } \\
\text { kegrafikan }\end{array}$ & 0,83 & Valid \\
\hline Total Rata-rata & $\begin{array}{c}0,83 \\
\text { Valid }\end{array}$ & \\
\hline
\end{tabular}

Tabel 3. Hasil Validasi Materi Modul

\begin{tabular}{|c|l|c|c|}
\hline No & \multicolumn{1}{|c|}{ Aspek } & Ratarata & Kategori \\
\hline 1 & $\begin{array}{l}\text { Aspek } \\
\text { Kualitas Isi }\end{array}$ & 0,88 & Valid \\
\hline 2 & $\begin{array}{l}\text { Aspek } \\
\text { Penyajian }\end{array}$ & 0,81 & Valid \\
\hline \multicolumn{2}{|l}{ Total Rata-rata } & $\begin{array}{c}0,85 \\
\text { valid }\end{array}$ & \\
\hline
\end{tabular}

Dari table 1 dan 2 terlihat nilai validasi format modul yang diberikan oleh 3 orang dosen ahli dibidang media yaitu memberikan total nilai rata-rata 0,83 . Sedangkan nilai validasi materi yang diberikan oleh 5 orang ahli bidang mata kuliah Teknologi Pangan yaitu memberikan nilai rata-rata 0,85 . Sehingga dapat disimpulkan bahwa modul pembelajaran mata kuliah Teknologi Pangan tersebut masuk pada kategori "Valid".

c. Tahap Uji Praktikalitas

a. Respon dosen terhadap praktikalitas modul pembelajaran mata kuliah TeknologiPangan dirangkum pada Tabel 4 di bawah ini.

Tabel 4. Rekapitulasi praktikalitas respon dosen

\begin{tabular}{|c|l|c|l|}
\hline \multirow{2}{*}{ No } & \multicolumn{1}{|c|}{$\begin{array}{c}\text { Indikator } \\
\text { enilaian }\end{array}$} & $\begin{array}{c}\text { Persentase } \\
\text { Nilai }\end{array}$ & Kategori \\
\cline { 2 - 4 } 1. $\begin{array}{c}\text { Rata-rata respon } \\
\text { psen }\end{array}$ & $96,9 \%$ & $\begin{array}{c}\text { Sangat } \\
\text { Praktis }\end{array}$ \\
\hline
\end{tabular}

b. Respon mahasiswa terhadap praktikalitas modul mata kuliah Teknologi Pangan

Tabel 5. Rekapitulasi praktikalitas respon mahasiswa

\begin{tabular}{|c|c|c|c|}
\hline No & Aspek Penilaian & Persentase & Kategori \\
\hline $\begin{array}{c}\text { Rata-rata respon } \\
\text { mahasiswa }\end{array}$ & $84,27 \%$ & $\begin{array}{c}\text { Sangat } \\
\text { Praktis }\end{array}$ \\
\hline
\end{tabular}

Uji praktikilitas modul pembelajaran pada mata kuliah Teknologi Pangan ini dinilai oleh dosen mata kuliah dan 
mahasiswa. Pada hasil penilaian tersebut menunjukkan bahwa rata-rata skor respon dosen adalah $96,9 \%$ dan rata-rata skor respon mahasiswa adalah $84,27 \%$ dengan kategori sangat praktis dan modul dapat dijadikan bahan pembelajaran bagi mahasiswa.

d. Tahap Uji Efektivitas modul pembelajaran mata kuliah Teknologi Pangan

Tabel 6. Hasil belajar mahasiswa kelompok control dan eksperimen.

\begin{tabular}{|c|r|r|c|c|}
\hline & $\begin{array}{l}\text { Tenggunakan } \\
\text { Modul } \\
\text { Eksperimen) }\end{array}$ & KriteriaMenggunakan & $\begin{array}{c}\text { Tanpa } \\
\text { Modul } \\
\text { (Kontrol) }\end{array}$ & Kriteria \\
\hline $\begin{array}{l}\text { Rata } \\
\text { rata }\end{array}$ & 77,36 & Lulus & 53,68 & $\begin{array}{r}\text { Tidak } \\
\text { lulus }\end{array}$ \\
\hline
\end{tabular}

Dari table 6 terlihat hasil belajar mata kuliah Teknologi Pangan di atas dapat disimpulkan bahwa pada kelas eksperimen (menggunakan modul) dari 22 orang mahasiswa lulus. Sementara pada kelas kontrol (tidak diberi perlakukan menggunakan modul) dari 22 orang mahasiswa terdapat 10 orang mahasiswa yang mendapatkan nilai yang tidak lulus. Rata-rata hasil belajar pada kelas eksperimen adalah 77,36 dengan kategori lulus dan pada kelas kontrol dengan ratarata 53, 68 dengan kategori tidak lulus.

\section{Pembahasan}

Pengembangan modul pembelajaran mata kuliah Teknologi Pangan serangkaian proses atau kegiatan yang dilakukan untuk menghasilkan suatu produk yang valid dan praktis.

a. Tahap Perancangan awal

Pada tahap perancangan modul pembelajaran mata kuliah Teknologi Pangan ini, langkah yang pertama penulis lakukan yaitu merancang modul pembelajaran sesuai dengan silabus mata kuliah Teknologi Pangan. Berdasarkan pendapat Nana Sudjana dan Ahmad Rivai (2007:133) langkah-langkah penyusunan modul pembelajaran Teknologi Pangan dirancang sesuai dengan panduan para ahli tersebut dan melakukan dengan pertimbangan isi dan desain yang terkandung didalamnya.

Hal yang sama juga dilakukan oleh Alif Satria Egar Santosa (2017:8), yaitu dalam perancangan media tahapan pertama yang dilakukan adalah menentukan mata pelajaran. Mata pelajaran yang digunakan dalam pengembangan modul ini adalah menganalisis kebutuhan. Analisis kebutuhan yang dilakukan adalah menganalisis materi yang sesuai dengan silabus.

Berdasarkan dari pendapat ahli di atas bahwa pada isi modul pembelajaran disesuaikan dengan silabus yang ada pada mata kuliah Teknologi Pangan. Sedangkan 
desain modul pembelajaran dipertimbangkan pada aspek tampilan yang dikembangkan. Setelah modul pembelajaran dibuat, maka selanjutnya dilakukan tahap validasi terhadap pakar yang bertujuan untuk menentukan layak atau tidaknya modul pembelajaran Teknologi Pangan tersebut.

\section{b. 2. Tahap Validasi}

Validasi modul pembelajaran mata kuliah Teknologi Pagan diperoleh dari tanggapan validator mengenai kevalitan modul pembelajaran yang dikembangkan. Validator terdiri dari delapan orang dosen sebagai validator format modul pembelajaran, tiga orang dosen Fakultas Teknik UNP dan lima orang sebagai validator isi materi modul, tiga orang dari dosen IKK UNP dan dua orang dosen STIKes Perintis yang mengajar mata kuliah Teknologi Pangan.

Validator format modul pembelajaran memberikan persentase rata-rata 0,83 dengan kategori valid. Validator materi memberikan persentase rata-rata 0,85 dengan kategori valid. Sesuai pendapat Azwar (2014: 113) hasil dari perhitungan aiken berkisar antara 0 sampai 1 dan angka 0,6 dapat diinterpretasikan memiliki koefisien cukup tinggi.

c. Tahap Uji Praktikalitas praktikalitas modul pembelajaran yang diperoleh dari angket yang diisi oleh dosen (dosen mata kuliah Teknologi Pangan). Hasil dari praktikalitas yang diberikan kepada dosen mengenai pengembangan modul pada kategori sangat praktis dengan persentase rata-rata 96,9\%, dan hasil praktikalitas yang diberikan kepada mahasiswa pada kategori sangat praktis dengan persentase rata-rata $84,27 \%$.

Hal yang sama juga dilakukan oleh Rumani (2014) bahwa pengembangan bahan hasil uji praktikaltas yang dinilai oleh praktisi dapat dikategorikan praktis, karena bahan ajar ini dapat dijadikan solusi bagi mahasiswa dan dosen.

\section{d. Tahap Uji Efektivitas}

Melihat keefektifan hasil belajar penggunaan modul pembelajaran ini dilakukan dengan posttest mahasiswa kelas control (kelas tidak menggunakan modul) dan kelas eksperimen (kelas menggunakan modul). Sesuai pendapat Slameto (1998: 81) "Efektifitas merupakan kesesuaian antara mahasiswa dengan hasil belajar". Dengan melihat hasil belajar kelas kontrol (tidak menggunakan modul) dari 22 orang mahasiswa didapat hasil rata-rata posttest $(53,68)$. Hasil belajar kelas ekperimen (menggunakan modul) dari 22 orang mahasiswa di dapat hasil untuk posttest 
(77,36). Posttest mahasiswa dapat dikatakan lulus apabila nilai mahasiswa $\geq$ 65 sesuai dengan ketentuan penilaian di STIkes yang telah ditetapkan oleh sekolah dengan mengerjakan soal tes sebanyak 35 soal.

Hal yang sama juga dilakukan oleh Iqma Novianty (2012) bahwa pengembangan hasil uji efektifitas yang dinilai dapat dikategorikan efektif. Hasil analisis ini dapat disimpulkan bahwa modul pembelajaran yang dikembangkan peneliti efektif digunakan untuk meningkatkan hasil belajar mahasiswa.

\section{KeSIMPULAN}

Berdasarkan hasil penelitian pengembangan modul pembelajaran yang telah dilakukan, maka diperoleh kesimpulan sebagai berikut:

1. Hasil validitas modul pembelajaran mata kuliah Teknologi Pangan dinyatakan valid pada aspek format modul rata-rata hasil validitas adalah 0,83 , pada aspek materi modul di dapat rata- rata validitas adalah 0,85 . Kategori tingkat pencapaian $\mathrm{V} 0,67$ dan di atasnya dinyatakan dalam kategori "Valid".

2. Praktikalitas modul dalam pembelajaran mata kuliah Teknologi Pangan dapat dilihat dari keterlaksanaan penggunaan modul pembelajaran secara keseluruhan baik. Ini terllihat dari respon dosen yang memperoleh persentase rata-rata $96.9 \%$, dan hasil respon mahasiswa yang memperoleh persentase rata-rata $84.27 \%$. Hal ini menunjukkan modul pembelajaran yang dikembangkan termasuk pada kategori "sangat praktis". Kategori tingkat pencapaian 81-100 \% "sangat praktis".

3. Efektivitas modul Teknologi Pangan yang dikembangkan dapat dilihat dari hasil posttest mahasiswa kelas control dan kelas eksperimen. Hasil kelas control (tidak menggunakan modul) dari 22 orang mahasiswa didapat hasil rata-rata posttest $(53,68)$ pada kategori "cukup efektif", dengan kriteria tingkat keberhasilan $41 \%$ $60 \%$. Hasil belajar kelas eksperimen (menggunakan modul) dari 22 orang mahasiswa didapat hasil untuk posttest $(77,36)$ pada kategori "efektif", dengan kriteria tingkat keberhasilan 61\%-80\%, jadi kenaikan antara kontrol dan eksperimen 23,68\%. Berdasarkan temuan peneltian ini disimpulkan bahwa modul pembelajaran pada mata kuliah Teknologi Pangan, valid, praktis, dan efektif untuk meningkatkan hasil belajar, dibuktikan dengan tingginya nilai rata-rata kelas eksperimen dari pada kelas control pada mahasiswa gizi STIKes Perintis Padang. 


\section{DAftar Pustaka}

Anwar, Ilham. 2010. Pengembangan Bahan Ajar. Bahan Kuliah Online UPI. Bandung.

Azwar Syaifuddin. 2014. Realibilitas dan Validitas. Yogyakarta: Pustaka Pelajar.

Depdiknas. 2008. Penulisan Modul. Direktorat Tenaga Kependidikan Nasional.

Ganefri dan Hendra Hidayat. 2013. Perspektif Kurikulum Pendidikan Kejuruan. Padang: Fakultas Teknik

Riduwan. 2010. Belajar Mudah PenulisanUntuk Guru-Karyawan dan Peneliti Pemula. Bandung: Alfabeta.

Slameto. 1998. Evaluasi Pendidikan. Jakarta: Bina Aksara.

Sudjana, Nana \& Rivai, Ahmad. 2007.

Teknologi Pengajaran. Bandung:

Sinar Baru Algesindo.

Satria Egar Santosa. Alif. 2017. Pengembangan E-Modul Berbasis Model Pembelajaran Problem Based Learning Pada Mata Pelajaran Administrasi Jaringan Kelas Xii Teknik Komputer Dan Jaringan di Smk Bali Global Singaraja. Bali: Unversitas Pendidikan Ganesha.

Sudijono, Anas. 2009. Pengantar evaluasi pendidikan. Jakarta: Raja grafindo persada.

Trianto. 2009. Mendesain Model Pembelajaran Inovatif-Progresif. Jakarta: Kencana.

Trianto. 2012. Mendesain Model Pembelajaran Inovatif-Progresif. Jakarta: Kencana Predana Media Group.

Winkel W.S. 2009. Psikologi Pendidikan dan Evaluasi Belajar. Jakarta: Gramedia. 